\title{
Retention time of feed particles and liquids in the stomachs and intestines of dairy cows. Direct measurement and calculations based on faecal collection
}

\author{
M Mambrini ${ }^{1}$, JL Peyraud * \\ Station de recherches sur la vache laitière, Inra, 35590 Saint-Gilles, France
}

(Received 24 April 1996; accepted 2 June 1997)

\begin{abstract}
Summary - To validate a method for analysing indigestible marker excretion patterns in terms of digesta passage, the mean retention time (MRT) of long hay, ground hay and concentrate, marked, respectively, with thulium, ytterbium and dysprosium was measured in the total digestive tract (TMRT) and in the stomachs (SMRT) of four cows fed on a diet of hay in the long form $(17.7 \mathrm{~kg}$ DM/day). The MRT of the particulate and liquid phases in the intestines was obtained after faecal particles labelled by Europium and Chromium-EDTA were pulse dosed through the duodenal cannula. Following test meals, total faecal collection and spot sampling of duodenal digesta were performed at fixed intervals. TMRT were $51.7,45.6,40.6 \mathrm{~h}$ and SMRT were $39.5,31.9$ and $28.0 \mathrm{~h}$, respectively, for hay, ground hay and concentrate. The MRT of the liquids in the rumen $(8.7 \mathrm{~h})$ was shorter than the SMRT of particles but there was no differential passage between liquids and particles after the duodenum. Intestinal MRT averaged $11 \mathrm{~h}$ and was partitioned into 7.5 and 3.5, respectively, for MRT in the tubular sections and the caecum-proximal colon. The compartmental analysis of the faecal patterns of markers given during a test meal gives the following results. The time associated with the descending part of faecal kinetics (respectively, 25.3 and $22.9 \mathrm{~h}$ for hay and concentrate) is directly related to the escape of feed particles from the rumen. The delay of first appearance of markers mostly reflects transit in the post duodenal tubular sections for the concentrate. The time associated with the ascending part (respectively, 16.9 and $9.4 \mathrm{~h}$ for hay and concentrate) represents the time required to reduce the size of the forage particles ( $7 \mathrm{~h}$ according to the difference between TMRT of long and ground hay direct measurements) and caecal mixing ( $3.5 \mathrm{~h})$ as well as other compartments or processes that are not clearly identified.
\end{abstract}

dairy cow / transit / particle / liquid / rumen / intestine

\footnotetext{
* Correspondence and reprints

Tel (33) 02992851 00; fax (33) 02992851 01; e-mail: peyraud@st-gilles.rennes.inra.fr
} 
Résumé - Temps de séjour des particules d'aliment et des liquides dans les estomacs et l'intestin des vaches laitières. Mesures directes et calcul à partir des cinétiques d'excrétion fécale des marqueurs. Pour estimer à partir des cinétiques d'excrétion fécale des marqueurs le transit dans les principaux compartiments digestifs, le temps de séjour moyen (MRT) de particules de foin long, de foin broyé et de concentré, marquées respectivement avec du thulium, de l'ytterbium et du dysprosium, a été mesuré dans l'ensemble du tube digestif (TMRT) et dans les estomacs (SMRT) sur quatre vaches laitières alimentées avec un régime à base de foin non haché $(17,7 \mathrm{~kg} \mathrm{MS} / \mathrm{j})$. Le MRT dans les intestins (IMRT) des particules et des liquides a été mesuré à partir de l'excrétion fécale de particules de fecces marquées avec de l'europium et du chrome-EDTA introduits par la canule du duodénum. Après les repas test, les fèces ont été collectées en totalité et des prélèvements de contenus duodénaux ont été effectués à intervalles fixés. TMRT a été de 51,$7 ; 45,6 ; 40,6 \mathrm{~h}$ et SMRT a été de 39,$5 ; 31,9 ; 28,0 \mathrm{~h}$ respectivement pour le foin, le foin broyé et le concentré. Le transit des liquides dans le rumen $(8,7 \mathrm{~h})$ a été beaucoup plus court que celui des particules mais il n'y a pas eu de passage différentiel des liquides et des particules dans les intestins. Le MRT dans les intestins a été de $11 \mathrm{~h}$ qui ont été répartis en $7,5 \mathrm{~h}$ de transit dans les compartiments tubulaires et $3,5 \mathrm{~h}$ dans le caecum-colon proximal. La durée associée à la phase décroissante des cinétiques d'excrétion fécale $(25,3$ et $22,9 \mathrm{~h}$ pour le foin et le concentré) traduit assez fidèlement la sortie des particules d'aliment du rumen. Le délai d'apparition des marqueurs $(9,5$ et $8,3 \mathrm{~h}$ pour le foin et le concentré) reflète principalement le transit dans les portions tubulaires situées après le duodénum. Le temps associé à la phase croissante (16,9 et $9,4 \mathrm{~h}$ pour le foin et le concentré) représente le temps requis pour réduire la taille des particules de foin long (estimé à 7,0 h par la différence entre les TMRT des foins entier et broyé), le transit dans le caecumcolon proximal et d'autres phénomènes qui n'ont pu être identifiés clairement.

\section{vache laitière / transit / particule / liquide / rumen / intestin}

\section{INTRODUCTION}

In ruminants, the extent to which dietary components are fermented in the reticulorumen is dependent on the mean retention time (MRT) of feed particles. Feed intake and MRT are also closely related. MRT in different sections of the gastro intestinal (GI) tract can be estimated after killing animals (O'Connor et al, 1984) but is more often derived from a single dose of a marker followed by time sequence samplings (Faichney, 1975a). Because of the difficulties in obtaining representative samples for particulate markers in the rumen, there have been many attempts to estimate the ruminal MRT of feed from the mathematical analysis of marker excretion in faeces. The GI tract has been assigned to two (Grovum and Williams, 1973) or sometimes three (Faichney and Griffiths, 1978; Milne et al, 1978) time-independent compartments sep- arated by tubular segments. Dhanoa et al (1985) proposed to describe the digesta flow along the GI tract by a multi compartmental process with two major compartments and a series of segmental mixing compartments each having a very low MRT. A family of models using gamma age dependency in the first compartment was also proposed (Pond et al, 1988; Quiroz et al, 1988) because it generally improved the quality of curve fitting (Quiroz et al, 1988).

However, difficulties have sometimes been encountered in fitting the compartmental models (Ellis et al, 1979; Milne et al, 1978; Dhanoa et al, 1985; Mambrini, 1990; Lallès et al, 1991). All these models differ by the way they fit the ascending part of the curve, which is based only on a few points. From a study of more than 60 patterns obtained in dairy cows, Mambrini (1990) showed that these curves are very 
sensitive to the initial data and inferred that no confidence could be placed in the estimations of the lower MRT because it varied with the different models. The subsequent difficulty is to attribute a biological significance to the partial MRT obtained from modelling. Despite the number of comprehensive studies comparing partial MRT generated by different models (Lallès et al, 1991; Huhtanen and Kukkonen, 1995) there are surprisingly few meaningful comments upon the biological significance of the compartments derived from mathematical analysis. In the study of Grovum and Williams (1973) the MRT in the rumen was always longer than the MRT in the caecum-proximal colon (hereafter called caecum) and it has become common practice to assume that the longer MRT represents rumen outflow. However in some circumstances, rumen MRT can be shorter than MRT in caecum (Faichney and Boston, 1983). In their model, Pond et al (1988) considered that the reduction of particle size within and outflowing from the rumen was the major factor but they did not make reference to the anatomical compartments. Finally, all these models assume that the flow of digesta is continuous throughout the GI tract, which is obviously not correct since defecation occurs at discrete times.

The present study was designed: 1) to gain knowledge concerning the MRT of feed particles and liquids in the whole GI tract or an anatomical section of it and on the MRT required for forage particle size reduction (Poppi et al, 1981); 2) to test a simple mathematical treatment of the faecal excretion curve that would be less sensitive to the initial data and to the discontinuity of defecation than the models currently used; 3) to attribute physiological significance to the two compartments and to the delay generated by calculations. Preliminary results of this work have been published (Peyraud and Mambrini, 1992).

\section{MATERIALS AND METHODS}

\section{Animals and feeding}

Four Holstein cows $(625 \pm 30 \mathrm{~kg}$ body weight, $20 \pm 4 \mathrm{~kg} /$ day fat corrected milk, 36 weeks of lactation) with a ruminal and $T$ piece duodenal cannula were housed in metabolic crates and milked twice daily. They were fed a diet consisting of (in percent of total DM) 55 perennial rye grass hay (not chopped), 42 concentrate, 1 soya bean meal, 1.6 mineral mix, 0.4 urea ad libitum. The animals were allowed $10 \%$ refusals. The ingredients of the concentrate, chemical composition and nutritive values of feeds are given in table I. The cows were fed two equals meals daily $(8 \mathrm{~h} 00,17 \mathrm{~h} 00)$ and they had free access to water and to block salt.

\section{Principles and organisation of measurements}

The MRT within the GI tract (TMRT) and the stomachs (SMRT, reticulo-rumen, omasum and abomasum) of foodstuffs (concentrate and hay) were determined by following the excretion patterns of markers in the faeces and duodenum after the cows were given a test meal. The MRT of the liquids and particles after the duodenum were measured by introducing a solute marker and labelled faecal particles through the duodenal cannula and following their faecal excretion. The MRT required for hay particle size reduction was calculated by the difference between the MRT of hay as fed (mean particle size $>100 \mathrm{~mm}$ ) and hay ground through a $2 \mathrm{~mm}$ screen (mean particle size $=0.6 \mathrm{~mm}$ ).

The experimental period consisted of 14 days of adaptation to the diet and metabolic crates, followed by a 9 day collection phase. To evaluate the differential passage rates simultaneously on the same animal, six different markers were used. Hays, concentrate and faecal particles were labelled with rare earth metals. Fed hay was marked with thulium (Tm-H) or with ytterbium before grinding ( $\mathrm{Yb}-\mathrm{GH})$, concentrate was labelled with dysprosium (Dy-C) and faecal particles were labelled with europium (Eu-F). Chromium-EDTA (Cr-EDTA) was used for measuring the intestinal transit of liquids, and polyethylene glycol (PEG) was used to estimate the ruminal fractional outflow rate of liquids (FOR). The choice of rare earth elements was 
Table I. Chemical composition and nutritive value of perennial rye grass hay and concentrate.

\begin{tabular}{|c|c|c|c|}
\hline$(g / k g D M)$ & Hay & Concentrate 1 & Soy bean meal \\
\hline Dry matter $(\mathrm{g} / \mathrm{kg})^{2}$ & 932 & 887 & 890 \\
\hline Organic matter ${ }^{3}$ & 902 & 903 & 927 \\
\hline Crude protein ${ }^{4}$ & 151 & 123 & 485 \\
\hline Neutral detergent fiber 5 & 656 & 200 & 116 \\
\hline Acid detergent fiber ${ }^{5}$ & 323 & 87 & 202 \\
\hline Acid detergent lignin 5 & 33 & 21 & 28 \\
\hline Net energy (UFL/kg DM) & 0.74 & 1.11 & 1.10 \\
\hline \multirow{2}{*}{$\begin{aligned} \text { Metabolizable protein } & \text { (g PDIE/kg DM) } \\
& \text { (g PDIN/kg DM) }\end{aligned}$} & 91 & 104 & 361 \\
\hline & 94 & 84 & 395 \\
\hline
\end{tabular}

I (in \% DM) 33 maize, 25 wheat, 20 barley, 10.5 wheat bran, 5 dehydrated alfalfa, 1.7 beet molasses, 1 fat, $3.8 \mathrm{~min}$ erals; ${ }^{2} 80^{\circ} \mathrm{C}, 48 \mathrm{~h} ;{ }^{3} 550{ }^{\circ} \mathrm{C}, 5 \mathrm{~h} ;{ }^{4} \mathrm{Kjeldahl}$ method, crude protein $=6.25 \times$ total $\mathrm{N} ;{ }^{5}$ on Fibertec (Tecator) according to Giger and Pochet (1987).

justified because the MRT of feed particles is not influenced by the nature of the rare earth element used (Goetsch and Galyean, 1983; Moore et al, 1992) and also because non-radioactive $\mathrm{Dy}, \mathrm{Eu}, \mathrm{Yb}$ and $\mathrm{Tm}$ are easily determined by atomic absorption.

\section{Marker preparations}

Rare earth markers were bound to particles following the competitive binding technique adapted from Ellis and Beever (1984) and Poncet (pers comm). Feedstuffs and faecal particles were boiled $\left(80^{\circ} \mathrm{C}\right.$ for $\left.1 \mathrm{~h}\right)$ in a commercial detergent without EDTA (Ergamatic AC, Société Chimiotechnique, Lyon, France) to remove the cell soluble. The cell wall residues were soaked at room temperature in a solution containing the rare earth element $(20 \mathrm{~g} / \mathrm{kg} \mathrm{DM})$ together with citric acid as a competitive ligand, and sufficient water to cover the material. $\mathrm{pH}$ was brought to 2.2-2.5 using $2 \mathrm{~N} \mathrm{HCl}$. After $24 \mathrm{~h}$ of soaking with occasional stirring, the labelled material was strained through cheesecloth and carefully rinsed with tap water to remove any unbound marker and dried at $60^{\circ} \mathrm{C}$ for $48 \mathrm{~h}$. Faecal particles were obtained by sampling the faeces excreted over a $24 \mathrm{~h}$ period from the four cows on day 10 . The faeces were mixed, dried and labelled with europium in the same way as the feed particles. The rare earth concentrations in the labelled par- ticles were 7.0, 7.0, 11.2, $4.5 \mathrm{~g} / \mathrm{kg} \mathrm{DM}$, respectively, for Tm-H, Yb-GH, Dy-Co and Eu-F.

Cr-EDTA solution was prepared according to Binnert et al (1968) and diluted, so that the final concentration was $1.5 \mathrm{~g} \mathrm{Cr} / \mathrm{L}$. The solution of PEG was obtained by dissolving 25 g PEG 4000 per $\mathrm{kg}$ DM intake in $1 \mathrm{~L}$ of warm water.

\section{Marker administration, duodenal digesta and faeces sampling}

On day 15 at $8 \mathrm{~h} 00,500 \mathrm{~g} \mathrm{Tm}-\mathrm{H}$ and $300 \mathrm{~g}$ Dy$\mathrm{C}$ were offered to each cow. Thirty minutes were allowed for eating the marked feeds then, any uneaten labelled feed was introduced into the rumen after being soaked in warm $\left(38^{\circ} \mathrm{C}\right)$ artificial saliva. The cows were then allowed to eat the usual morning meal. At $10 \mathrm{~h} 00,300 \mathrm{~g} \mathrm{Yb}$ GH were introduced into the middorsal to midventral regions of the rumen. At $11 \mathrm{~h} 00,50 \mathrm{~g}$ of Eu-F and $250 \mathrm{~mL}$ of Cr-EDTA were introduced through the duodenum cannula after being mixed in some heated duodenal contents $\left(39^{\circ} \mathrm{C}\right)$ that had been previously sampled on the same animals on day 10 and stored at $4{ }^{\circ} \mathrm{C}$. On day 21 at $8 \mathrm{~h} \mathrm{00,} \mathrm{PEG} \mathrm{was} \mathrm{pulse-dosed} \mathrm{into} \mathrm{the} \mathrm{rumen}$ (ventral sac).

The total faecal output was collected 22 times over the $178 \mathrm{~h}$ post-dosing. The sampling times were $6,10,12,16,20,24,28,32,36,48,54$, 
$60 \mathrm{~h}$ post-dosing and then every $12 \mathrm{~h}$, the midpoint of the meal being considered as time 0 . At each sampling time, faeces were weighed, thoroughly mixed and approximately $500 \mathrm{~g}$ were dried $\left(80^{\circ} \mathrm{C}\right.$ for $\left.48 \mathrm{~h}\right)$. Faecal samples were ground through a $0.8 \mathrm{~mm}$ screen and analysed for Tm, Yb, Eu, Dy and Cr. Spot samples of duodenal digesta were collected over $144 \mathrm{~h}$ after the test meal at $1.5 \mathrm{~h}$ intervals (from 0 to $20 \mathrm{~h}$ postdosing), $3 \mathrm{~h}$ intervals (from 20 to $43 \mathrm{~h}$ postdosing), $6 \mathrm{~h}$ intervals (from 43 to $67 \mathrm{~h}$ ) and $12 \mathrm{~h}$ intervals thereafter. They were freeze dried and ground through a $0.8 \mathrm{~mm}$ screen before analysis of $\mathrm{Tm}, \mathrm{Yb}$ and Dy. Rumen fluid was sampled at $10 \mathrm{~h} 00,10 \mathrm{~h} 30$ and $11 \mathrm{~h} 00$ on days 21 and 22 , strained through six layers of cheesecloth and stored at $4{ }^{\circ} \mathrm{C}$ until PEG analysis (on day 23).

\section{Chemical analysis}

Concentrations of PEG were analysed using Hyden's turbidimetric method (1955) as modified by Malawer and Powell (1967). Rare earth metals and chromium were determined by atomic absorption spectrophotometry (Varian, AA-20) using a nitrous oxide/acetylene flame. Chromium was extracted according to the method described by Siddons et al (1985). For rare earth analysis, the samples were ashed $\left(550^{\circ} \mathrm{C}\right.$ for $\left.6 \mathrm{~h}\right)$ and digested in a solution containing $2 \%$ nitric acid and $2 \mathrm{~g} / \mathrm{L}$ of potassium chloride. Wavelengths chosen were $357.8,371.8,398.8,421.2$, $459.4 \mathrm{~nm}$, respectively, for chromium, Tm, Yb, Dy and Eu. Previous studies had indicated that there was no interaction when the four rare earth metals and the chromium were present together (Mambrini, 1990).

\section{Calculations}

FOR was estimated as the slope of the natural logarithm regression of PEG concentration vs time post-dosing. The total MRT within the entire GI tract (TMRT) of fed hay, ground hay and concentrate and intestinal transit time (IMRT) of faecal particles and liquids were obtained, respectively, from the quantities of markers $\mathrm{Tm}-\mathrm{H}, \mathrm{Yb}$ GH, Dy-C, Eu-F, Cr-EDTA excreted in faeces, using the equation:

$$
\text { TMRT and IMRT }=\sum \mathrm{m}_{\mathrm{i}} \mathrm{t}_{\mathrm{i}} / \Omega \mathrm{m}_{\mathrm{i}}
$$

where $t_{i}$ is the time elapsed between dosing and the mid point of each interval i during which faeces were collected, and $m_{i}$ is the quantity of marker excreted during the ith interval. This method, based on the quantitative recovery of markers does not make any assumptions regarding the pattern of excretion.

SMRT of fed hay, ground hay and concentrate were calculated using the equation:

$$
\text { SMRT }=\sum c_{i_{i}} \mathrm{dt}_{\mathrm{i}} / \sum \mathrm{c}_{\mathrm{i}} \mathrm{dt}_{\mathrm{i}}
$$

where $c_{i}$ is the concentration of the marker in the duodenal digesta in the ith sample collected at the time $t_{i}$ and $\mathrm{dt}_{\mathrm{i}}$ is the time elapsed between two successive sampling times. This method assumes that the flow of digesta is continuous. The intestinal transit time for fed hay, ground hay and concentrate was calculated by subtracting SMRT from TMRT.

Compartmental analysis of faecal and duodenal passage curves was performed by a simple graphical method derived from that proposed by Uden (1984). Natural logarithm of the marker concentration was plotted against time. The concentration curves were then divided up in a descending part (compartment of greater residence time, MRT1), an ascending part (corresponding to a second mixing compartment with MRT2 as mean retention time) and a delay (TT). For faecal kinetics, the delay $\left(\mathrm{TT}_{\mathrm{fec}}\right.$ ) was determined by the time elapsed between dosing and the mid point of the interval when the marker appeared for the first time. MRT $1_{\mathrm{fec}}$ was calculated as the reverse of the slope of the descending part of the curve. MRT $2_{\text {fec }}$ corresponding to the ascending part of the curve was obtained by subtracting MRT $1_{\text {fec }}$ and TT $_{\text {fec }}$ from TMRT. Similar calculations were performed for the duodenal sampling site (MRT1 duo, TT $_{\text {duo }}$ and MRT2 duo $)$.

\section{Statistical analysis}

Total and partial retention times obtained from the duodenal and faecal excretions of $\mathrm{Tm}-\mathrm{H}, \mathrm{Yb}$ $\mathrm{GH}$ and Dy-C were analysed according to a splitplot design using the following model: $\mathrm{Y}_{\mathrm{ijk}}=$ $\mathrm{F}_{\mathrm{i}}+\mathrm{C}_{\mathrm{j}}+\mathrm{S}_{\mathrm{k}}+\mathrm{S}_{\mathrm{k}} \mathrm{F}_{\mathrm{i}}+\mathrm{S}_{\mathrm{k}} \mathrm{C}_{\mathrm{j}}+\mathrm{F}_{\mathrm{i}} \mathrm{C}_{\mathrm{j}}+\mathrm{e}_{\mathrm{ijk}}$ where $\mathrm{F}_{\mathrm{i}}=$ feed effect ( $\mathrm{i}=1$ to 3 ); $\mathrm{C}_{\mathrm{j}}=$ cow $\operatorname{\text {effect}}(\mathrm{j}=1$ to 4$)$; $S_{k}=$ sampling site effect $(k=1$ to 2$) ; S_{k} F_{i}$ and $\mathrm{S}_{\mathrm{k}} \mathrm{C}_{\mathrm{j}}=$ interaction site $\times$ feed and site $\times$ cow, respectively, $F_{i} C_{j}=$ interaction feed $\times$ cow and 
$\mathrm{e}=$ error term with $6^{\circ}$ of freedom. Feed and cow effects were tested with $F_{i} \times C_{j}$ as an error term.

Data obtained from the faecal excretion of markers introduced into the duodenum were analysed according to the following equation: $\mathrm{Y}=$ $\mathrm{P}_{\mathrm{i}}+\mathrm{C}_{\mathrm{j}}+\mathrm{e}_{\mathrm{ij}}$ where $\mathrm{P}_{\mathrm{i}}=$ labelled phase (particle or liquid); $C_{j}=$ cow effect and $e_{i j}=$ error term with $3^{\circ}$ of freedom.

Retention times of Tm-H, Yb-GH, Dy-C within the intestine were compared to the IMRT of Eu-F and Cr-EDTA according to the following model: $Y_{i j k}=S_{i}+M_{j}\left(S_{i}\right)+C_{k}+S_{i} C_{k}+e_{i j k}$ where $S_{i}=$ site of dosing $(i=1$ to 2$)$; $M_{j}=$ marker/feed effect ( $i=1$ to 5 ), $C_{k}=$ cow effect $(k=1$ to 4$)$; and $e_{i j k}=$ error term with $9^{\circ}$ of freedom. Site effect was tested with $\mathbf{M}_{\mathrm{i}}$ as an error term. When the effect was significant, means were compared by the Newman and Keul's test at the 0.05 significance level. All analyses were performed using the GLM procedure of SAS (1987). Correlation was tested with the CORR procedure of SAS (1987).

\section{RESULTS}

\section{Direct measurements}

SMRT was always shorter $(P<0.001$; table II) but highly correlated $(\mathrm{r}=0.98$; $n=12$ ) with TMRT. SMRT accounted for 76 and $70 \%$ of TMRT, respectively, for fed hay and concentrate. No interaction between feed and site of sampling was detected. TMRT and SMRT of marked feed particles decreased in the order $\mathrm{Tm}-\mathrm{H}>\mathrm{Yb}$ $\mathrm{GH}>\mathrm{Dy}-\mathrm{C}(P<0.01$; table II). In particular, the difference between fed hay and ground hay was similar for TMRT and

Table II. Total and partial mean retention times (h) in the total digestive tract and the stomachs (reticulo-rumen + omasum + abomasum) in dairy cows fed on a hay diet (data are means of four cows).

\begin{tabular}{|c|c|c|c|c|c|c|c|c|c|}
\hline \multirow{4}{*}{ Total MRT $^{3}$} & \multirow[b]{2}{*}{$\begin{array}{c}\text { Sampling } \\
\text { site }\end{array}$} & & \multirow[b]{2}{*}{$\begin{array}{c}\text { Fed } \\
h a y \\
(T m-H)\end{array}$} & \multirow{2}{*}{\multicolumn{2}{|c|}{$\begin{array}{l}\text { Ground Concen- } \\
\text { hay trate } \\
(Y b-G H)(D y-C)\end{array}$}} & \multirow[b]{2}{*}{$R S D I^{1}$} & \multirow[b]{2}{*}{$R S D 2^{2}$} & \multicolumn{2}{|c|}{ Significance } \\
\hline & & & & & & & & Site & $\begin{array}{l}\text { Site } x \\
\text { feed }\end{array}$ \\
\hline & Faeces & TMRT & $51.7^{\mathrm{a}}$ & $45.6^{\mathrm{b}}$ & $40.6^{\mathrm{c}}$ & 2.88 & 0.82 & $<0.001$ & NS \\
\hline & Duodenum & SMRT & $39.5^{c}$ & $31.9^{d}$ & $28.0^{\mathrm{e}}$ & & & & \\
\hline \multirow[t]{2}{*}{$\mathrm{MRT}^{4}$} & Faeces & $\mathrm{MRTI}_{\mathrm{fec}}$ & $25.3^{\mathrm{a}}$ & $24.3^{\mathrm{ab}}$ & $22.9^{\mathrm{bc}}$ & 2.07 & 1.36 & NS & NS \\
\hline & Duodenum & $\mathrm{MRT}_{\text {duo }}$ & $25.3^{\mathrm{a}}$ & $22.6^{\mathrm{bc}}$ & $21.4^{\mathrm{c}}$ & & & & \\
\hline \multirow[t]{2}{*}{$\mathrm{TT}^{5}$} & Faeces & $\mathrm{TT}_{\mathrm{fec}}$ & $9.5^{\mathrm{a}}$ & $10.5^{\mathrm{a}}$ & $8.3^{\mathrm{a}}$ & 0.95 & 0.092 & $<0.001$ & NS \\
\hline & Duodenum & $\mathrm{TT}_{\text {duo }}$ & $2.3^{\mathrm{c}}$ & $1.6^{\mathrm{c}}$ & $2.2^{\mathrm{c}}$ & & & & \\
\hline \multirow[t]{2}{*}{$\mathrm{MRT}^{6}$} & Faeces & $\mathrm{MRT}_{\mathrm{fec}}$ & $16.9^{\mathrm{a}}$ & $10.9^{b}$ & $9.4^{\mathrm{bc}}$ & 2.24 & 1.71 & $<0.001$ & NS \\
\hline & Duodenum & MRT2 duo & $11.9^{\mathrm{b}}$ & $7.7^{\mathrm{c}}$ & $4.4^{\mathrm{d}}$ & & & & \\
\hline \multirow[t]{2}{*}{$\mathrm{TT}+\mathrm{MRT} 2$} & Faeces & $(\mathrm{TT}+\mathrm{MRT} 2)_{\mathrm{fec}}$ & $26.4^{\mathrm{a}}$ & $21.4^{\mathrm{b}}$ & $17.7^{\mathrm{c}}$ & 2.07 & 0.84 & $<0.001$ & NS \\
\hline & Duodenum & $(\mathrm{TT}+\mathrm{MRT} 2)_{\mathrm{duo}}$ & $14.2^{\mathrm{d}}$ & $9.3^{\mathrm{e}}$ & $6.7^{\mathrm{f}}$ & & & & \\
\hline
\end{tabular}

\footnotetext{
${ }^{1}$ Standard deviation of the feed $\times$ cow effect, used as an error term for the analysis of feed effect; ${ }^{2}$ residual standard deviation of the model; ${ }^{3}$ total mean retention time; ${ }^{4}$ mean retention time corresponding to the descending part of the faecal excretion curves, $;$ delay of first appearence of the marker; ${ }^{6}$ mean retention time corresponding to the increasing part of the faecal excretion curves. Within and between sampling sites, different superscripts indicate significant differences between means $(P<0.05)$.
} 
SMRT (6.1 vs $7.6 ; P>0.10$ ). These two estimates of time for particle size reduction were highly correlated $(r=0.94, n=4)$ and the slope of the relation did not differ from $1(P>0.10)$. Estimated MRT within the intestines (TMRT-SMRT) did not differ $(P>0.10)$ among the three feeds (table III) and the mean value was $12.9 \mathrm{~h}$. The IMRT of Eu-F and Cr-EDTA were similar (table III) and averaged $10.5 \mathrm{~h}$. This value was shorter $(P<0.03)$ than the time calculated by the difference between TMRT and SMRT. FOR was $11.5 \% / \mathrm{h}$ so that the liquid retention time in the rumen was $8.7 \mathrm{~h}$, a value which is much lower than the SMRT of the feeds. Variance analysis showed significant individual variations (sd of cow effect was 9.5 and $5.8 \mathrm{~h}$, respectively, for TMRT and SMRT). Two cows showed a much lower retention time $(\mathrm{TMRT}=37.9 \mathrm{~h}$,

Table III. Total mean retention time of feed residues, particulate and liquid phases of the duodenal contents of the intestines of dairy cows (IMRT, $h$ ) fed on a hay $\operatorname{diet}^{l}$ (data are means of four cows).

\begin{tabular}{|c|c|c|c|}
\hline Dosing site & $\begin{array}{l}\text { Sampling } \\
\text { site }\end{array}$ & $\begin{array}{c}\text { Marker/ } \\
\text { feed }^{1}\end{array}$ & $I M R T$ \\
\hline Per os & $\begin{array}{l}\text { Faeces and } \\
\text { duodenum }\end{array}$ & $\begin{array}{c}\text { Tm-H } \\
\text { Yb-GH } \\
\text { Dy-C }\end{array}$ & $\begin{array}{l}12.2 \\
13.8 \\
12.6\end{array}$ \\
\hline Duodenum & Faeces & $\begin{array}{c}\text { Eu-F } \\
\text { Cr-EDTA }\end{array}$ & $\begin{array}{l}10.4 \\
10.7\end{array}$ \\
\hline $\begin{array}{l}\text { RSD1 }^{2} \\
\text { RSD2 }^{3} \\
\text { Effect of site } \\
\text { Effect of feed }\end{array}$ & & & $\begin{array}{l}1.36 \\
1.92 \\
0.03 \\
\text { NS }\end{array}$ \\
\hline
\end{tabular}

\footnotetext{
${ }^{1}$ For details see text. For Tm-H, Yb-GH and Dy-C mean retention time in the intestines was calculated by difference between TMRT in total digestive tract and in stomachs; ${ }^{2}$ standard deviation of the feed and/or duodenal phase effect, used as an error term for analysis of effect of the sites of dosing; ${ }^{3}$ residual standard deviation of the model.
}

SMRT $=25.5 \mathrm{~h}$ ) than the other two animals $(\mathrm{TMRT}=45.4 \mathrm{~h}, \mathrm{SMRT}=32.1 \mathrm{~h})$.

\section{Compartmental analysis of faecal and duodenal patterns of markers given during the test meal}

The shape of the marker concentration curves in the duodenal samples were not as regular as in the faecal samples (fig 1), presumably due to the greater difficulty in obtaining representative samples through the duodenal cannula as compared to total faecal collection. Consequently, fitting the descending part of the excretion curves of $\mathrm{Tm}-\mathrm{H}, \mathrm{Yb}-\mathrm{GH}$ and $\mathrm{Dy}-\mathrm{C}$ to an exponential model explained $99 \%$ of the variance for faecal curves with only one value lower than $98 \%$ but it was less than $98 \%$ on five occasions for the duodenal curves. MRT1 generated from the analysis of faecal marker concentration was lower but highly correlated with estimates based on calculations performed from the quantities of markers excreted ( 24.3 vs $26.3 \mathrm{~h} ; \mathrm{r}=0.91, n=12$, $P<0.05)$. The differences reached $4 \mathrm{~h}$ in three kinetics but were lower than $1 \mathrm{~h}$ for the other kinetics.

The MRT associated with the descending part of the curves (MRT1) were not affected by the sampling site $(P>0.10$; table II). $M R T 1_{f e c}$ and MRT1 $1_{\text {duo }}$ were highly correlated (table V) but the slope of the relation was significantly different from 1 . The markers appeared in the faeces during the third or the fourth sampling interval, while in the duodenal contents, they appeared as soon as the first sample (fig 1) in 10 out of the 12 excretion kinetics. It was thus not possible to estimate $\mathrm{TT}_{\text {duo }}$ and MRT2 $2_{\text {duo }}$ precisely although the sum $\mathrm{TT}_{\text {duo }}+$ MRT2 $2_{\text {duo }}$, obtained by substracting MRT1 ${ }_{\text {duo }}$ from SMRT, was not biased. In such cases, $\mathrm{TT}_{\text {duo }}$ was determined as half the time elapsed between dosing and the first sampling time. MRT2 $2_{\text {duo }}$ was signifi- 


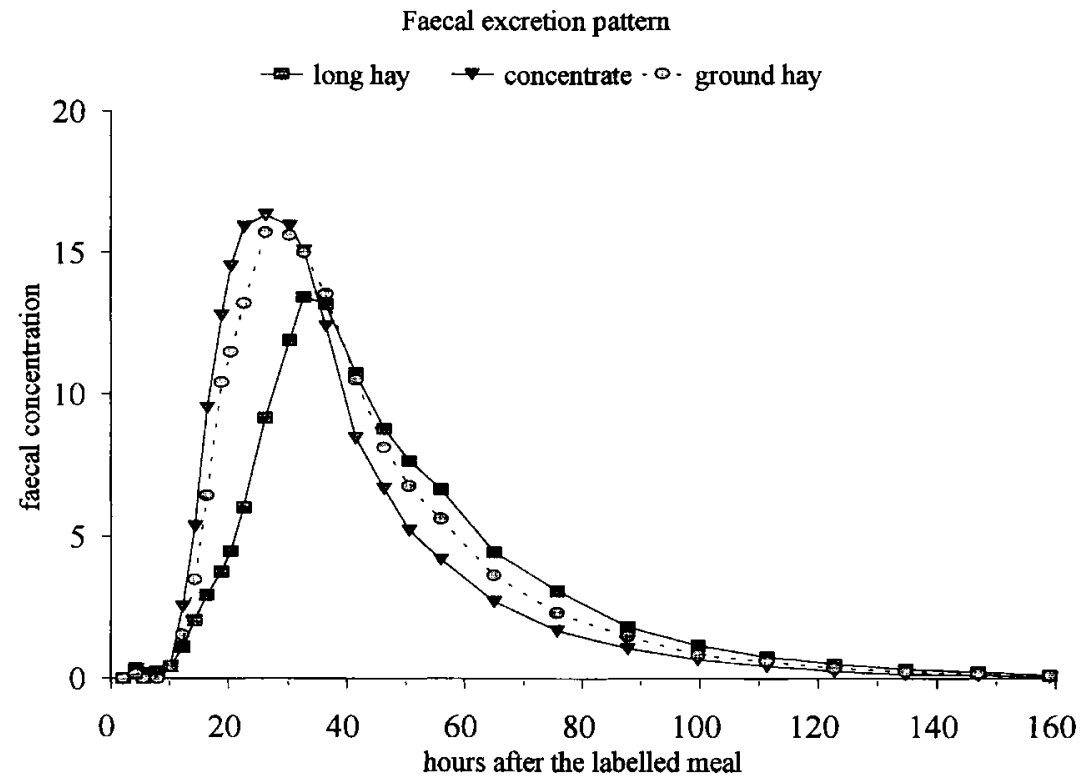

Duodenal excretion pattern

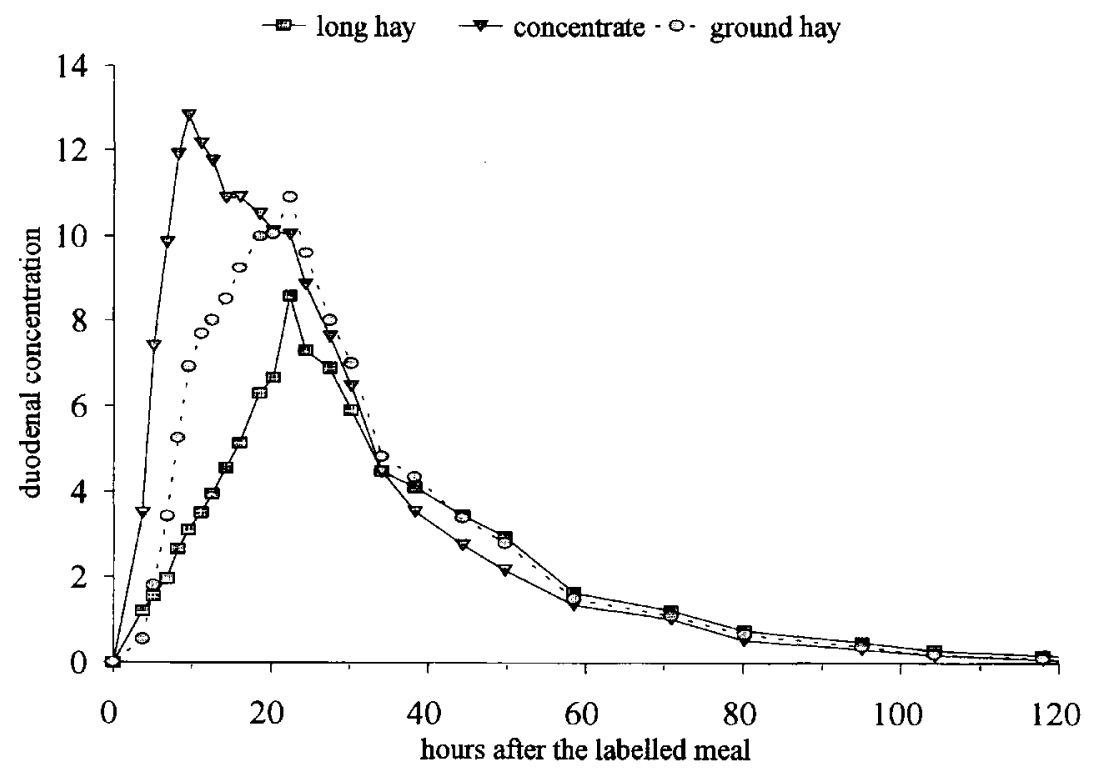

Fig 1. Faecal and duodenal excretion patterns of rare earth element labelled particles given as a meal (long hay and concentrate) or dosed into the rumen (ground hay) of dairy cows fed on a hay diet. Values are means of four individual measurements. (Concentration are expressed in $\mathrm{g} \cdot \mathrm{kg} \mathrm{DM}^{-1} \cdot \mathrm{g}^{-1}$ marker recovered.) 
cantly shorter $(P<0.001)$ when calculated from duodenal rather than from faecal sampling $(P<0.001)$. $\mathrm{TT}_{\text {duo }}$ was on average $7.5 \mathrm{~h}$ shorter than $\mathrm{TT}_{\mathrm{fec}}$ and $\mathrm{MRT} 2_{\text {duo }}$ was $4.4 \mathrm{~h}$ shorter than MRT2 $_{\text {fec }}$ (table II).

There was no site $\times$ feed interaction for the estimation of MRT1, MRT2 and TT. $\mathrm{MRT}_{\text {fec }}$ did not differ between Tm-H and $\mathrm{Yb}-\mathrm{GH}$, and was slightly longer than for Dy-C. MRT1 $1_{\text {duo }}$ was slightly higher for Tm$\mathrm{H}$ compared to $\mathrm{Yb}-\mathrm{GH}$ and Dy-C. The delay was not affected by the nature of the feed $(P>0.10$; table II). On the contrary MRT2 was markedly affected by the feeds, these latter being in the order long hay $>$ ground hay $>$ concentrate $(P<0.001)$. In particular, the differences in total transit time between fed and ground hays were mostly attributable to MRT2 in the whole GI tract (TMRT) as well as in the stomachs (SMRT).

The total time spent in the two compartments generated from the analysis of faecal excretion curves (TMRT1 + TMRT2) for Tm-H, Yb-GH and Dy-C was $3.3 \mathrm{~h}$ longer but highly correlated with SMRT (table V). The slope of the relationship did not differ from $1(P>0.10)$.
Table IV. Partial mean retention time calculated from the faecal excretion pattern obtained after labelled particles $(\mathrm{Eu})$ and liquid (Cr-EDTA) were pulse-dosed into the duodenum of dairy cows fed on a hay diet (data are means for four cows).

\begin{tabular}{lcccc}
\hline & $\begin{array}{c}\text { Faecal } \\
\text { particles }\end{array}$ & $\begin{array}{c}\text { Liquid } \\
\text { phase }\end{array}$ & RSD $^{1}$ & $\begin{array}{c}\text { Statistical } \\
\text { effect }\end{array}$ \\
\hline $\mathrm{MRT1}^{2}$ & 2.7 & 3.5 & 0.42 & 0.07 \\
$\mathrm{TT}^{2}$ & 6.5 & 7.2 & 0.57 & 0.08 \\
$\mathrm{MRT}^{2}$ & 1.1 & 0.0 & 0.65 & NS \\
\hline
\end{tabular}

${ }^{1}$ Residual standard deviation; ${ }^{2}$ for details see table II.

\section{Compartmental analysis of faecal pattern of markers introduced into the duodenum}

A fairly similar pattern of Eu-F and $\mathrm{Cr}$ EDTA excretions was observed (fig 2, table IV). After a delay, the marker concentration reached a peak between two successive defecations and decreased thereafter. However there were small differences between Eu-F and Cr-EDTA in MRT1 and TT which tended to be significant. The delay

Table V. Mean difference (h) and correlations between total and partial mean retention time obtained after modelling faecal excretion patterns of markers and by direct measurements.

\begin{tabular}{|c|c|c|c|c|c|c|c|c|}
\hline & \multirow[b]{2}{*}{$\begin{array}{l}\text { Dependant } \\
\text { variable }\end{array}$} & \multirow[b]{2}{*}{$\begin{array}{c}\text { Independant } \\
\text { variable }\end{array}$} & \multirow[b]{2}{*}{$\begin{array}{c}\text { Mean } \\
\text { difference }\end{array}$} & \multicolumn{5}{|c|}{ Regression parameters ${ }^{1}$} \\
\hline & & & & Slope & Intercept & $n$ & $r$ & Syx \\
\hline \multicolumn{5}{|c|}{ Direct measurements } & $8.3^{* *}$ & 12 & 0.98 & 2.11 \\
\hline \multicolumn{9}{|c|}{ Mean retention time calculated from faecal excretion curves } \\
\hline $\begin{array}{l}\text { eq } 2 \\
\text { eq } 3 \\
\text { eq } 4\end{array}$ & $\begin{array}{l}(\mathrm{MRT} 1+\mathrm{MRT} 2)_{\mathrm{fec}}{ }^{3} \\
\mathrm{MRT}_{\mathrm{fec}}{ }^{4} \\
\mathrm{MRT1}_{\mathrm{fec}}{ }_{4}\end{array}$ & $\begin{array}{l}\text { SMRT } \\
\text { MRT1 }_{\text {duo }}{ }^{5} \\
\text { MRTLiq }^{6}\end{array}$ & $\begin{array}{c}3.3 \\
1.0 \\
15.2\end{array}$ & $\begin{array}{c}1.06 \\
0.73^{* *} \\
2.91^{* *}\end{array}$ & $\begin{array}{c}1.5 \\
7.3^{* *} \\
-1.8\end{array}$ & $\begin{array}{c}12 \\
12 \\
4\end{array}$ & $\begin{array}{l}0.98 \\
0.94 \\
0.88\end{array}$ & $\begin{array}{l}2.15 \\
2.13 \\
2.81\end{array}$ \\
\hline
\end{tabular}

\footnotetext{
1 Syx residual standard deviation, $\mathrm{r}$ correlation coefficient, slope and intercept different from 1 and 0 , respectively $\left({ }^{*} P<0.05 ;{ }^{* *} P<0.01\right) ;{ }^{2}$ total mean retention time in the digestive tract; ${ }^{3}$ total mean retention time in the stomachs; ${ }^{4}$ mean retention time corresponding to the descending part of the faecal excretion curves; ${ }^{5}$ mean retention time corresponding to the descending part of the duodenal excretion curves; ${ }^{6}$ mean retention time of liquids in the rumen.
} 


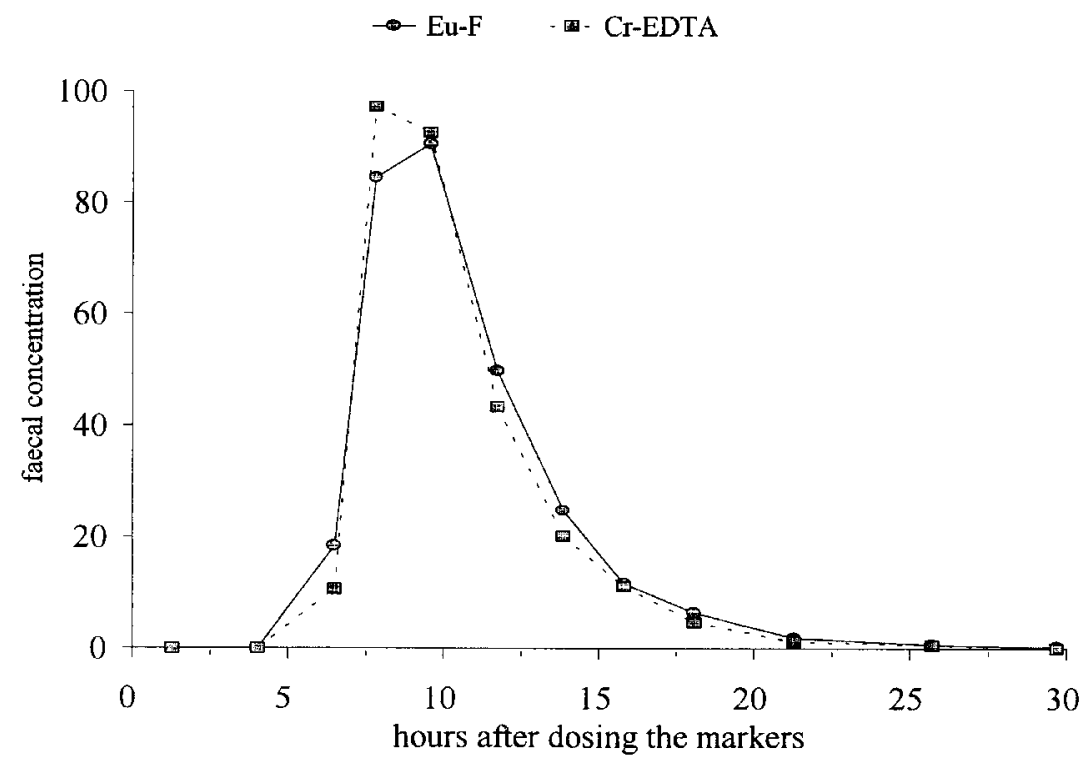

Fig 2. Faecal excretion pattern of europium labelled faecal particles (Eu-F) or Cr-EDTA dosed into the duodenum of dairy cows fed on a hay diet. Values are means of four individual measurements. (Concentration are expressed in g.kg DM ${ }^{-1} . \mathrm{g}^{-1}$ marker recovered.)

represented two thirds of IMRT. MRT1 averaged $3.2 \mathrm{~h}$. MRT2 was always very short and was most often not significantly different from zero. Negative values for MRT2 were obtained on two occasions for Cr-EDTA and this is biologically unrealistic. This compartment may thus be ignored.

\section{DISCUSSION}

\section{Choice of markers}

The migration of markers from labelled particles was assumed to be of little effect and the different rare earth elements were assumed to behave similarly in interpreting data on particle passage. Labelling techniques and choice of markers are crucial in estimating the MRT of particulate matter (Coleman et al, 1984; Faichney et al, 1989). Rare earth elements have been criticised because they may migrate from the labelled feed particles (Combs et al, 1992). In this study, particles were labelled using a competitive procedure (Ellis and Beever, 1984). It could therefore be expected that markers were selectively bound to a site on the feed particles having an association constant greater than that of citric acid ( $\mathrm{pK}>8.1$ ). Because the dissociation of bound rare earth elements may also occur at acidic segments such as the abomasum, the $\mathrm{pH}$ was brought to a value lower than 2.5 when labelling the feeds. These approaches for more tenacious binding of marker on feed particles would have minimised the eventual migration of the marker.

The choice of rare earth elements was also justified by their specific properties. Goetsch and Galyean (1983) compared Dy and $\mathrm{Yb}$ and showed that the feeds MRT were not influenced by the nature of the rare earth element used. Similarly, Moore et al 
(1992) reported that Dy, erbium and Yb had the same excretion pattern in sheep when they were labelling either hay or concentrate. Therefore it can be concluded that $\mathrm{Yb}$ and Dy were useful for comparing the MRT of concentrate and ground hay in our study. Moreover, $\mathrm{Tm}$ and $\mathrm{Yb}$ were chosen for labelling fed hay and ground hay, respectively, because these elements occupy related positions in the periodic table. They were assumed to exhibit similar affinities for hay cell walls as was the case for EDTA and metabolite molecules in the rumen (Allen and van Soest, 1984). As expected, rare earth element concentrations in labelled long and ground hay were identical $(7.0 \mathrm{~g} / \mathrm{kg} \mathrm{DM})$. Finally, because faecal particles have to be introduced into the duodenum with $\mathrm{Cr}$ EDTA, Eu was chosen for labelling faecal particles owing to its much lower association constant ( $\mathrm{pK}=17.4$ ) with EDTA compared to chromium and the three other rare earth elements $(\mathrm{pK}=24.0,19.5,19.3$ and 18.3 respectively for $\mathrm{Cr}, \mathrm{Yb}, \mathrm{Tm}$ and $\mathrm{Dy}$ ).

\section{Passage of particulate matter and liquids in the stomachs}

The TMRT of particles of fed hay and concentrate within the GI tract as well as liquid rumen FOR agree with data previously obtained on dairy cows (Hartnell and Satter, 1979; Uden, 1984). The results obtained in this experiment confirm that particulate matter is retained much longer in the stomachs of dairy cows than within the intestines (O'Connor et al, 1984). The MRT in the stomachs accounted for more than two thirds of the total MRT of the feed particles. Moreover, the differential passage of fed hay, ground hay and concentrate particles in the entire GI tract was fully explained by SMRT variations and the MRT in the intestines did not differ among feeds. SMRT can be considered as being mainly located in the reticulo-rumen. Actually particulate matter TMRT in abomasum and omasum lasts less than $4 \mathrm{~h}$ in sheep and cattle (Faichney and Griffiths, 1978; Huhtanen and Kukkonen, 1995) and might be even lower in dairy cows having a higher level of intake.

The longer MRT of Tm-H compared to $\mathrm{Yb}-\mathrm{GH}$ can be attributed to the time necessary for particle size reduction. Estimates of the time necessary to comminute coarse particles did not differ between the two sampling sites and averaged $6.9 \mathrm{~h}$. These data agree well with the mean ruminating time in dairy cows (6 to $8 \mathrm{~h}$, Jarrige et al, 1995), which is a process accounting for more than $80 \%$ of the comminution of large particles entering the rumen (Kennedy, 1985). The TMRT and SMRT of Yb-GH were on average $4.5 \mathrm{~h}$ longer than the TMRT and SMRT of Dy-C. The critical size theory (Poppi et al, 1981) divides the rumen particles into two pools: a large particle pool, which cannot pass out of the rumen and a small particle pool, which can flow out of the rumen. When estimating the time necessary to reduce particle size from the difference between fed hay and ground hay TMRT, we assume that ground hay particles belong to the small particle pool and that their behaviour is similar to that of particles arising from the mastication of the long marked hay. But a further size reduction for ground hay can not be excluded. Grenet (1970) and Dixon and Milligan (1985) reported that small particles $(<0.6 \mathrm{~mm})$ accounted for half of the faecal particles in steers fed with long hay. Shaver et al (1988) demonstrated that ground hay was ruminated by dairy cows at a rate of $20 \mathrm{~min} / \mathrm{kg}$ DM, ie, $5.5 \mathrm{~h}$ for an intake level similar to that of our animals. In addition, specific gravity has been shown to be an important physical criterion influencing passage (Ehle and Stern, 1986) and differences in functional specific gravity between ground hay and concentrate should not be excluded. Because of a much faster rate of fermentation, the density of particles may increase more rapidly for concentrate than for forage particles. 
The MRT of liquids in the reticulo-rumen was four times shorter than the MRT of particulate matter. The processes taking place in the reticulo-rumen are likely to be responsible for this differential passage rate, as previously observed in dairy cows (Prange et al, 1982). The observed difference between liquid and particulate transit is lower than the one reported for sheep ( 1.5 to 2.5 times; Faichney, 1975b; Poncet et al, 1986). Sheep spend a longer time chewing than do cows (Carle and Dulphy, 1980) and the amount of small particles, which absorb water, is greater in the swallowed bolus of sheep (Michalet-Doreau et al, 1992). The rumen contents are consequently more stratified in cows than in sheep (Poppi et al, 1981), explaining the relative independence of liquid and solid phases in the rumen of the cow.

\section{Passage of particulate matter and liquids in the intestines}

The MRT of liquid and faecal particles introduced into the duodenum were similar, indicating that, on the contrary to what happens in the rumen, no differential passage of liquid and solid digesta occurs in the intestines. This is the reverse of what happens in the reticulo-rumen. These results agree with data previously obtained in sheep (Faichney and Boston, 1983), cattle (Huhtanen and Kukkonen, 1995) and cow (Van Bruchem et al, 1981). The value for intestinal MRT are within the limits reported by O'Connor et al (1984), Prange et al (1982) and Shaver et al (1988) for dairy cows. These values appear to be lower than those obtained for sheep (22 h on average; Coombe and Kay, 1965; Faichney, 1975b). This could be explained either by differences in the gut architecture between the two species (namely the caecum) or by the higher intake level of cows. It was shown in dairy cows that intestinal MRT decreases from $20 \mathrm{~h}$ in cows given $6.5 \mathrm{~kg}$ DM (Pond et $\mathrm{al}, 1988$ ) to $8 \mathrm{~h}$ when DM intake increases to $23.7 \mathrm{~kg} \mathrm{DM}$ per day (Poore et al, 1991).

Intestinal MRT of particles was higher when estimated by the difference between total MRT derived from faecal and duodenal sampling than when calculated from the faecal excretion pattern of markers introduced into the duodenum. It is unlikely that the faecal particles have a longer MRT than hay particles because the intestinal MRT did not differ between Tm-H, Yb-GH and Dy-C. The origin of this bias remains unclear. Nonetheless the difference was small and may not be biologically significant. It can be considered that $11 \mathrm{~h}$ are spent by feed particles in the intestines. This low MRT implies that the digestibility of fibre after the duodenum would be low and could not compensate for a decrease in ruminal digestibility at higher levels of intake or with diets containing high amounts of starch.

Being able to follow faecal kinetics of markers introduced through the duodenal cannula allowed the MRT of the intestine to be partitioned. Particle and liquid MRT in the intestines can be described by a delay of $7.5 \mathrm{~h}$ and one mixing compartment of $3.2 \mathrm{~h}$ on average. This compartment can be considered as located in the caecum. This estimate of caecal MRT is within the limits reported in other studies when direct measurements were made after killing animals (2 to 5 h, Mäkelä, 1965; Miller et al, 1967). The delay was higher than direct estimates of MRT in the small intestine (2 to $4 \mathrm{~h}$, Mäkelä, 1965 ; Miller et al, 1967). Assuming that the delay is also associated with the tubular segments of the hindgut, the MRT in such segments might last for $4 \mathrm{~h}$.

\section{Interpretation of the parameters derived from faecal excretion curves}

The declining phase of the marker excretion pattern was similar whether described at the duodenal or at the faecal level. This indi- 
cates that the preduodenal segments are at the origin of MRT $1_{\mathrm{fec}}$. Moreover, because $M R T 1_{\text {fec }}$ did not differ between fed hay and ground hay on the one hand, and is correlated with liquid MRT in the reticulo-rumen on the other, $\mathrm{MRT}_{\mathrm{fec}}$ may be allocated with confidence to the reticulo-rumen and directly related to the escape of dietary particles from it. The anatomical and physiological identifications of this mixing compartment agrees with other studies (Grovum and Williams, 1973; Ellis et al, 1979). In some circumstances, namely in sheep, the rumen MRT can be shorter than the caecum MRT and in such a case, the MRT1 will reflect this latter compartment (Faichney and Boston, 1983). This does not appear to be the case for dairy cows (Mambrini, 1990; Mambrini and Peyraud, 1994). Between feeds, the difference in MRT1 calculated from the faecal excretion of markers may be biased, because the slope of the relationship between $M R T 1_{\text {fec }}$ and MRT $1_{\text {duo }}$ (0.73) differs from 1. Faecal analysis may have underestimated the longer retention times and overestimated the shorter ones. However, the difficulty in obtaining representative samples of the duodenal contents (Faichney, 1975a) may explain this bias and the fairly good agreement between $M R T 1_{\text {fec }}$ calculated from the analysis of the concentration curves or the amounts of marker excreted supports the use of faecal samples.

Numerous comparisons have emphasised the difficulty to obtain, with models, accurate estimations of TT and partial MRT assigned to the second mixing compartment, ie, the delay and the ascending part of the curve (Dhanoa et al, 1985; Lallès et al, 1991). In the present experiment the delay of first appearance of markers in faeces was determined experimentally, it was only subject to analytical errors. TT was $7.4 \mathrm{~h}$ longer (on average) when estimated from faecal sampling than from duodenal sampling. These results are consistent with the reported data (between 7 and $10 \mathrm{~h}$; Prange et al, 1982; Pond et al, 1988). The difference between
$\mathrm{TT}_{\text {fec }}$ and $\mathrm{TT}_{\text {duo }}$ was numerically equivalent and highly correlated within the four cows with the delay of first appearance in the faeces of markers introduced into the duodenum $(r=0.94)$. This shows that $\mathrm{TT}_{\mathrm{fec}}$ reflects mostly transit in the tubular segments after the duodenal cannula. It may also represent a delay occurring before the duodenum due to a slow mixing of marked feeds in the rumen or during transit through omasum. In the present experiment, the nature of foodstuff did not influence $\mathbf{T T}_{\mathrm{fec}}$, although $\mathrm{TT}_{\mathrm{fec}}$ tended to be longer for hay than for concentrate. Indeed a greater difference between forages and concentrates for $\mathrm{TT}_{\text {fec }}$ has been reported (Mambrini and Peyraud, 1994). Our results indicate that this could not be explained by a faster intestinal transit of concentrate particles. These differences could therefore be attributed to a supplementary mixing delay in the case of forages. Actually the lower density of forage particles could have been responsible for a slower mixing of the marked forage in the rumen (Martz and Belyea, 1986), or in the omasum or, as already demonstrated by Welch and Palmer (1987), for the driving back of these particles from omasum to reticulum. Concentrate $\mathrm{TT}_{\mathrm{fec}}$ seems to be more clearly assigned to transit in the tubular segments than does the forage $\mathrm{TT}_{\text {fec }}$.

Differences between Tm-H and $\mathrm{Yb}-\mathrm{GH}$ in TMRT and SMRT were mainly explained by the variations in MRT2 $2_{\text {fec }} . M R T 2_{\text {fec }}$ probably represents the time required to reduce the size of forage particles. Retention time in the second compartment was affected by sampling site. MRT2 was on average $4.4 \mathrm{~h}$ longer for faecal than for duodenal sampling and the total time spent in the two compartments derived from faecal excretion curve (sum MRT $1_{\mathrm{fec}}+\mathrm{MRT}_{\mathrm{fec}}$ ) was on average $3.4 \mathrm{~h}$ longer than SMRT. Thus, MRT2 $2_{\text {fec }}$ does not represent processes confined to the reticulo-rumen alone but also reflects compartmental mixing in the post-duodenal segments. This compartment 
should be the caecum because these differences were fairly similar to the values of MRT1 ${ }_{\text {duo }}$, which is assumed to be the time spent in the caecum. Assuming a MRT of $3 \mathrm{~h}$ for the caecal mixing compartment and $7 \mathrm{~h}$ for forage particle size reduction, there are still 5 to $7 \mathrm{~h}$ that remains unexplained for the partial time assigned to the second mixing compartment after faecal curve analysis. This time period can be partitioned between other compartments or processes for which no data are available in this study. It could be expected that the retention time in the abomasum and omasum MRT, which averaged 3 to $4 \mathrm{~h}$ (Faichney and Griffiths, 1978), must also be assigned to MRT $2_{\mathrm{fec}}$. Nonetheless because the MRT of feed particles did not differ after the reticulo-rumen, it is worthwhile noting that the difference in MRT $2_{\mathrm{fec}}$ between forage and concentrate gives an index of the time necessary to reduce the particle size of coarse forage.

\section{CONCLUSIONS}

In dairy cows, information on retention time in the reticulo-rumen can be deduced from measurements of the faecal excretion curves for ingested markers. Calculation of total mean retention time from the quantities of markers excreted gives relevant indications of the reticulo-rumen retention time variations because the latter largely governs variations in the former. The mathematically simple method presented here for analysing such data provides answers to questions pertaining to the passage of ingesta. MRT assigned to the decreasing part of the marker concentration pattern represents the escape of particles from the rumen ( 25 and $23 \mathrm{~h}$ for hay and concentrate, respectively). Delay for first appearance of the markers ( 9 to $10 \mathrm{~h}$ and $8 \mathrm{~h}$ for hay and concentrate, respectively) depends mainly on the transit in the tubular sections after the duodenum $(7.5 \mathrm{~h}$ on average) and to a smaller extent before the duodenum for concentrates. Mixing of the marked feeds in the rumen and some small indistinct phenomena for forages also takes longer. Indications on the time for forage particle size reduction (eg, $7 \mathrm{~h}$ ) may be deduced from the differences between MRT assigned to the increasing part of the excretion pattern of labelled forage and concentrate particles ( 17 and $9 \mathrm{~h}$ for hay and concentrate, respectively). The remaining time $(9 \mathrm{~h})$ represents the retention time in caecum $(3 \mathrm{~h})$ and 5 to $7 \mathrm{~h}$ that could represent the retention time in the abomasum and other processes taking place in the reticulorumen.

\section{ACKNOWLEDGMENTS}

We wish to thank AG Deswysen, C Poncet and $R$ Vérité for their helpful criticism, $H$. Hétault and his crew for the care of the animal and technical assistance, and A Brasseur for the chemical analysis.

\section{REFERENCES}

Allen MS, van Soest PJ (1984) Periodicity and variation in the binding of rare earth ions to plant cell wall particles. In: Technique and Particle Size Analysis of Feed and Digesta in Ruminants (PM Kennedy, ed), Canadian Society of Animal Science, occasional publication no 1 , Edmonton, $\mathrm{AB}$, Canada, 180-183

Binnert WT, Van Klooster AT, Frens AM (1968) Soluble chromium indicator measured by atomic absorption in digestion experiments. Vet Rec 82 , 470

Carle B, Dulphy JP (1980). Comportement alimentaire comparé des ovins et bovins. Relation avec la digestion des aliments. Reprod Nutr Dev 20, 1633-1639

Coleman SW, Evans BC, Horn GW (1984) Some factors influencing estimates of digest turnover rate using markers. J Anim Sci 58, 979-986

Coombe JB, Kay RNB (1965) Passage of digesta through the intestines of the sheep. Retention times in the small and large intestines. BrJ Nutr 19, 325338

Combs DK, Shaver RD, Satter LD (1992) Retention of rare earths by hay particles following incubation in fresh or autoclaved rumen fluid. $J$ Dairy $S_{c i} 75$, 132-139 
Dhanoa MC, Siddons RC, France J, Gale J (1985) A multicompartmental model to describe marker excretion patterns in ruminant faeces. $\mathrm{Br} J \mathrm{Nutr}$ $53,663-671$

Dixon RM, Milligan LP (1985) Removal of digesta components from the rumen of steers determined by sieving techniques and fluid, particulate and microbial markers. Br J Nutr 53, 347-362

Ehle FR, Stern MD (1986) Influence of particle size and density on particulate passage through alimentary tract of holstein heifers. J Dairy $S_{c i} 69$, 564-568

Ellis WC, Beever DE (1984) Methods for binding rare earth to specific feed particles. In: Technique and Particle Size Analysis of Feed and Digesta in Ruminants (PM Kennedy, ed), Canadian Society of Animal Science, occasional publication no 1, Edmonton, AB, Canada, 154-165

Ellis WC, Matis JH, Lascano C (1979) Quantitating ruminal turnover. Fed Proc 38, 2702-2706

Faichney GJ (1975a) The use of markers to partition digestion within the gastrointestinal tract of ruminant. In: Digestion and Metabolism in the Ruminant (IW McDonald, ACI Warner, eds), The University of New England, Sidney, Australia, 277-291

Faichney GJ (1975b). The effect of formaldehyde treatment of a concentrate diet on the passage of solute and particle markers through the gastrointestinal tract of sheep. Austr J Agric Res 26, 319-327

Faichney GJ, Griffiths DA (1978) Behaviour of solute and particle markers in the stomach of sheep given a concentrate diet. BrJ Nutr 40,71-81

Faichney GJ, Boston RC (1983) Interpretation of the fecal excretion pattern of solute and particle markers introduced into the rumen of sheep. J Agric Sci Camb 101, 575-581

Faichney GI, Poncet C, Boston RC (1989) Passage of internal and external markers of particulate matter through the rumen of sheep. Reprod Nutr Dev 29, 325-337

Giger S, Pochet S (1987) Méthodes d'estimation des constituants pariétaux dans les aliments destinés aux ruminants. Bull Tech CRZV Theix Inra, Paris, France 70, 49-60

Goestch AL, Galyean ML (1983) Ruthenium phenantroline, dysprosium and ytterbium as particulate markers in beef steers fed an all-alfalfa hay diet. Nutr Rep Int 27, 171- 175

Grenet E (1970) Taille et structure des particules végétales au niveau du feuillet et des fèces chez les bovins. Ann Biol Anim Bioch Biophys 10, 643-657

Grovum WL, Williams VJ (1973) Rate of passage of digesta in sheep. 4. Passage of marker through the alimentary tract and the biological relevance of rate-constants derived from the changes in concentration of marker in faeces. Br J Nutr 30, 313329

Hartnell GF, Satter LD (1979) Determination of rumen fill retention time and ruminal turnover rates at dif- ferent stages of lactation in dairy cows. J Anim Sci 48, 381-392

Huhtanen P, Kukkonen U (1995) Comparison of methods, markers, sampling sites and models for estimating digesta passage kinetics in cattle fed at two levels of intake. Anim Feed Sci Tech 52, 141-158

Hyden S (1955) A turbidimetric method for turbidimetric determination of higher polyethylene glycols in biological materials. Ann Roy Agric Coll Sweden 21, 139-145

Jarrige R, Dulphy JP, Faverdin P, Baumont R, Demarquilly $C$ (1995) Activités d'ingestion et de rumination. In: Nutrition des ruminants domestiques $(\mathrm{R}$ Jarrige, Y Ruckebush, C Demarquilly, MH Farce, M Journet, eds), Inra Paris, France 124-181

Kennedy PM (1985) Effect of rumination on reduction of particle size of rumen digesta by cattle. Aust J Agric Res 36, 819-828

Lallès JP, Delval E, Poncet C (1991) Mean retention time of dietary residues within the gastrointestinal tract of the young ruminant: a comparison of noncompartmental (algebraic) and compartmental (modelling) estimation methods. Anim Feed Sci Tech 35, 139-159

Mäkelä AC (1965) Studies on the question of bulk in the nutrition of farm animals with special reference to cattle. Suomen Maatloustieteellisin Seuran Jullkaisuja 85, 1-139

Malawer SJ, Powell DW (1967) An improved turbidimetric analysis of polyethylene glycol utilizing an emulsifier. Gastroenterology 53, 250-256

Mambrini M (1990) Étude du transit des aliments dans le tube digestif des vaches laitières : aspects méthodologiques et facteurs de variation. PhD Thesis, University of Rennes, France

Mambrini M, Peyraud JL (1994) Mean retention time in the digestive tract and digestion of fresh ryegrass by lactating dairy cows: influence of grass maturity and comparison with a maize silage diet. Reprod Nutr Dev 34, 9-23

Martz FA, Belyea R (1986) Forage utilization by the lactating cow. Role of particle size and forage quality in digestion and passage by cattle and sheep. $J$ Dairy Sci 69, 1996-2008

Michalet-Doreau B, Cerneau P, Dardillat C (1992) Comparaison de la granulométrie du bol mastiqué et de l'aliment broyé à différentes grilles : incidence sur la méthodologie des mesures in sacco. Ann Zootech 41, 70 (Abstr)

Miller JK, Perry SC, Chandler PT, Cragle RG (1967) Evaluation of radiocerium as non-absorbed reference material for determining rate of undigested residues in cattle. J Dairy Sci 57, 193-197

Milne JA, McRae JC, Spence AM, Wilson ST (1978) A comparison of the voluntary intake and digestion of a range of forages at different times of the year by sheep and the red deer. BrJ Nutr 40,347357 
Moore JA, Pond KR, Poore MH, Goodwin TG (1992) Influence of model and marker on digesta kinetic estimates for sheep. J Anim Sci 70, 3528-3540

O'Connor JD, Robinson PH, Sniffen CJ, Allen MS (1984) A gastrointestinal tract simulation model of digesta flow in ruminants. In: Techniques in Particle Size of Feed and Digesta in Ruminants (PM Kennedy, ed), Canadian Society of Animal Science, occasional publication no 1, Edmonton, AB, Canada, 102-122

Peyraud JL, Mambrini M (1992). Direct measurement of transit time in the stomachs and intestine of dairy cows. Ann Zootech 41, 55

Poncet C, Beaufort MT, Al Abd A (1986) Vitesse de passage des résidus alimentaires et des liquides dans le tube digestif du mouton selon le marqueur et le type de ration. Reprod Nutr Dev 26, 321-322

Pond KR, Ellis WC, Matis JH, Ferreiro HM, Sutton JD (1988) Compartmental models for estimating attributes of digesta flow in cattle. $B r J$ Nutr 60 , $571-595$

Poore MH, Moore JA, Eck TP, Swingle RS (1991) Influence of passage model, sampling site, and marker dosing time on passage of rare earth-labelled grain through holstein cows. J Anim Sci 69, 26462654

Poppi DP, Minson DJ, Ternouth JH (1981) Studies of cattle and sheep eating leaf and stem fractions of grasses. 2. Factors controlling the retention of feed in the reticulo-rumen. Aust J Agric Res 32, 109 121

Prange RW, Jorgensen NA, Satter LD (1982) Rate of passage calculation based on duodenal or faecal collection sites. J Dairy Sci 65, 145 (Abstr)

Quiroz RA, Pond KR, Tolley EA, Johnson WL (1988) Selection among nonlinear models for rate of passage studies in ruminants. J Anim Sci 66, 29772986

SAS (1987) Statistical Analysis Systems SAS/STAT. Guide for Personal Computers, version 6. SAS Institute, Cary, NC, USA

Siddons RC, Paradine J, Beever DF, Cornell PR (1985) Ytterbium acetate as a particulate digesta flow marker. Br J Nutr 54, 509-519

Shaver RD, Satter LD, Jorgensen NA (1988) Impact of forage fiber content on digestion and digesta passage in lactating dairy cows. J Dairy Sci 71, 15561565

Uden P (1984) The effect of intake and hay concentrate ration upon digestibility and digesta passage. Anim Feed Sci Tech 11,167-179

Van Bruchem J, Wiersma J, Van Adrichem PWM (1981) An evaluation of the use of chromic oxide, polyethylene glycol and Cr-EDTA as markers for digestive studies along small intestine of ruminants. Neth J Agr Sci 29, 151-162

Welch JG, Palmer RH (1987) Return of particles from the omasum to the rumen. J Anim Sci 65 (Suppl 1), 458 